\title{
NODAL THERMODYNAMIC AND DYNAMIC ANALYSIS OF A FREE DISPLACER STIRLING ENGINE
}

\author{
Can CINAR*, A. Onur OZDEMIR ${ }^{* *}$, Halit KARABULUT ${ }^{* * *}$ and Mesut DUZGUN**** \\ Department of Automotive Engineering, Faculty of Technology, Gazi University, 06560, Ankara, Turkey \\ *cancinar@gazi.edu.tr; ORCID: 0000-0001-6944-8864 \\ **onurozdemir@gazi.edu.tr; ORCID: 0000-0002-6475-1976 \\ ****halitk@gazi.edu.tr; ORCID: 0000-0001-6211-5258 \\ *****mduzgun@gazi.edu.tr; ORCID: 0000-0003-0582-4183
}

(Geliş Tarihi: 20.07.2020, Kabul Tarihi: 03.03.2021)

\begin{abstract}
In this study, the dynamic and thermodynamic features of free displacer Stirling engines were investigated by preparing a simulation program. The dynamic component of the simulation program involves the movement equations of power piston, crankshaft and displacer. The thermodynamic component is a nodal analysis based on 24 nodal volumes. The study indicates that starting these engines requires an initial speed is required as the displacer system natural frequency. While the engine is running, the displacer exhibits some secondary vibrations (named as beatings) and causes irregularities in its work and power generation however, it can be minimized by changing some working parameters such as displacer mass, working fluid mass, external loading, spring constant etc. For each value of the working fluid charging pressure, a different spring is needed. While the spring constant is the same, the displacer mass can vary in a limited range. The thermal performance of the engine increases as the displacer mass is decreasing. For an engine working between $1000 \mathrm{~K}$ heater temperature, $356 \mathrm{~K}$ cooler temperature and 18 bar charging pressure, the effective thermal efficiency ranges between 21 and $26 \%$. An engine with a 3.5 liter total inner volume is capable of generating about $3.9 \mathrm{~kW}$ effective power and $4.7 \mathrm{~kW}$ indicated power. A strong relation is observed between engine performance and phase angle.
\end{abstract}

Keywords: Dynamic and thermodynamic simulation, Free displacer Stirling engine, Performance prediction, Optimization of displacer mass, Optimization of spring constant.

\section{SERBEST DİSPLEYSIRLI BİR STİRLING MOTORUNUN NODAL TERMODINAMIK VE DINAMMIK ANALIZI}

Özet: Bu çalışmada, serbest displeysırlı Stirling motorlarının dinamik ve termodinamik özellikleri bir simülasyon programı hazırlanarak incelenmiştir. Simülasyon programının dinamik kısmı, güç pistonu, krank mili ve displeysırın hareket denklemlerini içermektedir. Termodinamik kısmında da 24 nodal hacme dayanan bir nodal analiz yapılmıştır. Çalışmada, bu motorları ilk harekete geçirmek için, displeysırın doğal frekansı olarak bir başlangıç hızı gerektiği görülmektedir. Motor çalışırken displeysır vuru olarak adlandırılan bazı ikincil titreşimler sergilemekte, bu durum iş ve güç üretiminde düzensizliklere sebep olmaktadır. Bu durum, displeysır kütlesi, çalışma maddesi kütlesi, harici yük ve yay sabiti gibi bazı çalışma parametreleri değiştirilerek en aza indirilebilir. Çalışma maddesi şarj basıncının her bir değeri için farklı bir yaya ihtiyaç duyulmaktadır. Aynı yay sabiti değeri için, displeysır kütlesi sınırlı bir aralıkta değiştirilebilmektedir. Displeysır kütlesi azalırken motorun termal performansı artmaktadır. $1000 \mathrm{~K}$ sıcak uç sıcaklığı ve $356 \mathrm{~K}$ soğuk uç sıcaklığı arasında ve 18 bar şarj basıncında çalışan bir motor için efektif termik verim \%21-26 arasındadır. 3,5 litre toplam iç hacme sahip bir motor, 3,9 kW efektif güç ve 4,7 kW indike güç üretebilmektedir. Motor performansı ile faz açısı arasında güçlü bir ilişki olduğu görülmektedir.

Anahtar Kelimeler: Serbest displeysır, Stirling motoru, Dinamik ve termodinamik simülasyon, Performans tahmini,Displeysır kütlesinin optimizasyonu, Yay sabitinin optimizasyonu.

\section{NOMENCLATURE}

$A_{v} \quad$ Heat transfer area of nodal volumes $\left[\mathrm{m}^{2}\right]$

$A_{R} \quad$ Regenerator heat transfer area $\left[\mathrm{m}^{2}\right]$

$c \quad$ Damping coefficient of displacer $[\mathrm{Ns} / \mathrm{m}]$

$C_{k m}$ Hydrodynamic friction coefficient of crank pin bearing [Nm.s]

$C_{m j} \quad$ Hydrodynamic friction coefficient of main journal bearing $[N m . s]$
$C_{q} \quad$ Torsional damping constant of dynamometer $[\mathrm{Nms} / \mathrm{rad}]$

$C_{v} \quad$ Specific heat at constant volume [ J/kg.K]

$F_{b} \quad$ The force applied by connecting rod to the piston, Fig. 3, $[N]$

$F_{b c} \quad$ The force applied by piston rod to the crank pin $[N]$

$F_{b x} \quad$ Horizontal component of $F_{b}[N]$ 
$F_{c h} \quad$ The force generated by crankcase pressure, Fig. 3, $[N]$

$F_{w} \quad$ The force generated by working volume pressure [N]

$F_{\infty} \quad$ Coulomb friction generated by piston ring $[N]$

$H \quad$ Length of piston $\operatorname{rod}[\mathrm{m}]$

$H_{i} \quad$ Enthalpy flowing into the nodal volumes [ $\left.J\right]$

$H_{o} \quad$ Enthalpy flowing out of the nodal volumes $[J]$

$h \quad$ Heat transfer coefficient, Fig. $4,\left[\mathrm{~W} / \mathrm{m}^{2} \mathrm{~K}\right]$

$h_{i} \quad$ Specific enthalpy flowing into the nodal volumes $[J]$

$h_{o} \quad$ Specific enthalpy flowing out of the nodal volumes $[J]$

$h_{p} \quad$ Dimension of piston above the pin, Fig. 3, $[\mathrm{m}]$

I Mass moment of inertia of the crankshaft $\left[\mathrm{kg} \cdot \mathrm{m}^{2}\right]$

$k \quad$ Stiffness of spring $[N / m]$

$m \quad$ Mass $[\mathrm{kg}]$

$M_{c} \quad$ The moment generated by $F_{b c}[\mathrm{Nm}]$

$m_{d} \quad$ Displacer mass, Fig. 5, $[\mathrm{kg}]$

$m_{g} \quad$ Mass of working fluid $[\mathrm{kg}]$

$m_{i} \quad$ Mass flow into the nodal volumes $[\mathrm{kg} / \mathrm{s}]$

$m_{o} \quad$ Mass flow out of the nodal volumes $[\mathrm{kg} / \mathrm{s}]$

$m_{p} \quad$ The mass of power piston $[\mathrm{kg}]$

$M_{q} \quad$ External load [ $\left.\mathrm{Nm}\right]$

$\bar{M}_{q} \quad$ The cyclic average of external load [Nm]

$M_{s} \quad$ Starter motor moment $[\mathrm{Nm}]$

$P_{e} \quad$ Effective power $[W]$

$P_{i} \quad$ Indicated power $[W]$

$p_{w} \quad$ Working space pressure [bar]

$p_{c h} \quad$ Crankcase pressure [bar]

$R \quad$ Crack radius [m]

$\mathfrak{R} \quad$ Gas constant $[\mathrm{J} / \mathrm{kg} . \mathrm{K}]$

$Q_{c} \quad$ Cold source heat [ $]$

$Q_{h} \quad$ Hot source heat [J]

$s \quad$ Stroke of displacer $[\mathrm{m}]$

$T_{c} \quad$ Cooler temperature, Fig. $4,[K]$

$T_{h} \quad$ Heater temperature, Fig. $4,[K]$

$T \quad$ Working fluid temperature $[K]$

$T_{w} \quad$ Wall temperature $[K]$

$V \quad$ Volume $\left[m^{3}\right]$

$W_{i} \quad$ Indicated work, Fig. 8, $W_{i}=\int_{0}^{2 \pi} P d V,[J]$

$W_{Q} \quad$ Indicated work from heats, $W_{Q}=Q_{h}-Q_{c}$, [J]

$x, y \quad$ Coordinate elements, Fig. $1,[\mathrm{~m}]$

$z \quad$ Displacer position, Fig. $1,[\mathrm{~m}]$

$\delta T$ Temperature difference between regenerator cells, Fig. $4,[K]$

$\Delta m \quad$ Mass variation in nodal volumes within time steps $[\mathrm{kg}]$

$\Delta Q \quad$ Heat exchange in nodal volumes within time steps $[J]$

$\Delta T \quad$ Temperature variation in nodal volumes within time steps $[K]$

$\Delta t \quad$ Time step $[s]$
$\Delta U \quad$ Internal energy variation in nodal volumes during time steps $[J]$

$\Delta V \quad$ Volume variation within time steps $\left[\mathrm{m}^{3}\right]$

$\Delta W \quad$ Work generation in nodal volumes within time steps $[J]$

$\alpha \quad$ Convection heat transfer coefficient $\left[\mathrm{J} / \mathrm{m}^{2} \mathrm{~K}\right]$

$\phi \quad$ Phase angle [ deg]

$\Omega \quad$ A dummy parameter

$\psi \quad$ The angle between the cylinder axis and connecting $\operatorname{rod}[\mathrm{rad}]$

$\sigma \quad$ Coolant friction coefficient

$\eta_{e} \quad$ Effective thermal efficiency [\%]

$\eta_{i} \quad$ Indicated thermal efficiency [\%]

$\omega \quad$ Nominal angular speed of crank shaft or engine $[\mathrm{rad} / \mathrm{s}]$

$\theta \quad$ Crank shaft angle, Fig. 1, $[\mathrm{rad}]$

\section{INTRODUCTION}

Stirling engine is a technology that can used to convert alternative energies into mechanical energy. Stirling engine is also eligible to improve the performance of the current energy conversion systems by hybridizing them with the Stirling engine. However, the current level of the Stirling technology is not sufficient to use them in industrial energy conversion systems. For the current situation at least 40 research teams are working on Stirling engines. Some of the recent research is presented in the following review of the literature.

Zhou et al. (Zhou et al, 2018) designed a miniature integrated nuclear reactor with reactor core and energy transfer system of the Stirling engine and a linear electric motor to convert fission energy into electric power. The authors analyzed the physical and thermodynamic properties and the safety performance of the nuclear reactor. It was concluded that the reactor could be used for space flight propulsion, Mars and the Moon base power supply and the deep sea applications. Kwankaomeng and coworkers (Kwankaomeng et al, 2014) conducted a thermodynamic and dynamic analysis of a free piston Stirling engine. The authors also manufactured and tested the free piston Stirling engine to evaluate the engine characteristic and performance. The engine provided $0.68 \mathrm{~W}$ maximum power at $6.4 \mathrm{~Hz}$ frequency with $10 \mathrm{~W}$ electrical heat supply. De la Bat et al. (De la Bat et al, 2020) described the thermodynamic and electrodynamic behavior of a free piston Stirling engine generator. To validate the numerical model, the linear generator and the free piston Stirling engine were tested and a good agreement was obtained with the numerical model. Zare and coworkers (Zare et al, 2020) investigated the performance of a free piston Stirling engine by describing the function technique and genetic algorithm. The authors predicted the amplitudes of the piston and displacer, operating frequency, phase angle, work and the output power. The simulation results were verified with the experimental data of SUTech-SR-1 prototype Stirling engine and a good agreement was obtained. Park et al. (Park et al, 2020) designed and tested a free piston Stirling engine equipped with a linear alternator. In the engine 
two identical power pistons were used to ensure balancing.

The engine was tested with helium at $525{ }^{\circ} \mathrm{C}$ heater temperature and $20^{\circ} \mathrm{C}$ cooler temperature using natural gas as fuel. The linear alternator produced $961 \mathrm{~W}$ at a frequency of $60 \mathrm{~Hz}$ and $23 \%$ overall efficiency was obtained. Chi and coworkers (Chi et al, 2020) developed a two-dimensional CFD model of a $100 \mathrm{~W}$ free piston Stirling engine using ANSYS Fluent. In the analysis, the variations of temperature and velocity field in the expansion chamber and compression chamber were investigated. The results of the simulation were compared with the experimental data using helium at 5 MPa. Tavakolpour-Saleh et al. (Tavakolpour-Saleh et al, 2017) conducted a comprehensive mathematical modeling on a novel free piston Stirling engine. The authors concluded that the output power and efficiency were obtained as $7.8 \mathrm{~W}$ and $19.2 \%$ at the operating frequency of $9.25 \mathrm{~Hz}$. An active Stirling convertor namely SUTech-SR-2, was used to verify the numerical results and generated about $3.1 \mathrm{~W}$ output power. Karabulut (Karabulut, 2011) investigated the dynamic model of a free piston Stirling engine. In the engine, the piston and displacer were connected to the engine casing with springs. The engine having $50 \mathrm{~mm}$ piston diameter produced $200 \mathrm{~W}$ power at $700 \mathrm{~K}$ heater temperature and 15 bar charging pressure. Zare and Tavakolpour-Saleh (Zare and Tavakolpour-Saleh, 2020) studied the self-starting conditions of a free piston Stirling engine using analytical solution and Lyapunov function. Two prototype oscillators, named SUTech-SR-1 and B10-B were used to verify the numerical simulation result. By comparing the simulation and experimental results, the authors concluded that this method precisely predicts the onset condition of free piston Stirling engines. Cheng and coworkers (Cheng et al, 2013) conducted the dynamic analysis of a thermal-lag Stirling engine. The authors optimized the brake thermal efficiency and engine power for different working parameters, such as bore, stroke and volume of the working spaces. The authors pointed out that, compared to other Stirling engine types relatively lower thermal efficiency was obtained with thermal-lag engines because the working fluid might not be swept effectively between the hot and cold compartments by the displacer. Masoumi and Tavakolpour-Saleh (Masoumi and Tavakolpour-Saleh, 2020) calculated the heat transfer and damping coefficients of an active free piston Stirling engine using a genetic algorithm. The authors also conducted two experimental tests for the identification of the heat transfer and damping coefficients. The identified parameters showed a good match with the experimental results. Majidniya et al. (Majidniya et al, 2020) carried out a study on a free-piston Stirling engine coupled with a permanent magnet linear synchronous generator. The authors modeled the free piston Stirling engine and validated the model with experimental results. They also modeled the permanent magnet linear synchronous machine and then combined the dynamic equations of these systems to obtain the best performance. Ye and coworkers (Ye et al, 2018) optimized the performance of a free piston Stirling engine using a regression model.
The authors obtained the output power, thermal and exergy efficiencies from the model. Operating and structural parameters such as hot and cooler temperatures, charging pressure, frequency, phase angle, lengths of heater and cooler were optimized to achieve maximum output power, thermal and exergy efficiencies. The error between the predicted and experimental results was found to be less than $5 \%$. Mou and Hong (Mou and Hong, 2017) analyzed a free piston Stirling engine using the experimental data. In the thermodynamic model, the non-isothermal effects, the regenerator effectiveness and the heat losses were taken into account. The authors calculated the output work, efficiency, pressure-volume variations and gas temperatures. Maximum output work and thermal efficiency were calculated as $120 \mathrm{~W}$ and 18 $\%$, respectively with $90 \mu \mathrm{m}$ piston gap and $80^{\circ}$ phase angle. Formosa (Formosa, 2011) conducted a coupled thermodynamic and dynamic analysis of a free piston Stirling engine. Thermal variables were defined using thermodynamic analysis, and the authors validated the model using experimental data from NASA RE-1000 free piston Stirling engine and a good agreement was obtained. Lin et al. (Lin et al, 2020) developed a free piston Stirling generator and high temperature potassium heat pipes. Sage software was used for the thermodynamic modeling. The novel free piston Stirling generator was manufactured to weigh only $4.2 \mathrm{~kg}$ and was coupled with the potassium heat pipe. The authors obtained $142.4 \mathrm{~W}$ output power and $17.4 \%$ thermal to electric conversion efficiency at a heater temperature of $574{ }^{\circ} \mathrm{C}$. Mehdizadeh and Stouffs (Mehdizzadeh and Stouffs, 2000) conducted the dynamic and thermodynamic analysis of a free piston Stirling engine with Martini configuration. In the engine the displacer was driven by an electric motor and two symmetrical free pistons were used. Helium was used as the working substance and the piston and the displacer diameters were $36 \mathrm{~mm}$ and $60 \mathrm{~mm}$. The authors concluded that the phase angle between the piston and displacer could be controlled by variable electrical resistance without any modification in engine geometry. Begot and coworkers (Begot et al, 2013) conducted the stability analysis of a free piston Stirling engine. In the analysis, the effects of operational and construction parameters such as mean pressure, hot source temperature, piston and displacer mass, pressure losses and dead volumes on the performance and stability were investigated. The numerical model was compared with the experimental results of the NASA RE1000 engine. It was obtained that regular mechanical parameters were obtained with large piston masses; however, more power was obtained with a light displacer. Wood and Lane (Wood and Lane, 2003) designed a free piston Stirling engine having linear alternator for space applications. The specific power of the engine was $100 \mathrm{~W} / \mathrm{kg}$ and thermal to electric conversion efficiency was more than $50 \%$ of Carnot. The authors compared the analysis results and test data of the Sunpower EG 1000 engine and small power level free piston Stirling engines. Abbas and coworkers (Abbas et al, 2011) investigated a $100 \mathrm{MW}$ solar power plant based on dish/Stirling technology for electricity production. The SAM software was used to evaluate monthly energy production, annual energy 
output and cost of energy. The authors concluded that Tamanrasset in Algeria is a suitable site for solar electricity production. Zhu et al. (Zhu et al, 2019) manufactured and tested a free piston Stirling engine combined with a parabolic trough collector. The optical and thermal losses of the Stirling engine/concentrated solar power system were analyzed. Test results showed that $2008 \mathrm{~W}$ maximum electric power with $15 \%$ thermal to electric efficiency were obtained at a heater temperature of $300^{\circ} \mathrm{C}$.

In free displacer Stirling engines the absence of mechanical linkage between the displacer and crankshaft provides some advantages such as more compact design, manufacturing simplicity, lower friction losses, longer life time and lighter weight etc. However, there is an uncertainty about the thermodynamic and dynamic behaviors of the engine. In a recent theoretical study, its dynamic behaviors were examined by Karabulut et al. (Karabulut et al, 2020) via a dynamic simulation where the gas force was calculated with an isothermal nodal model. In the isothermal nodal model, the gas temperatures in the compartments are assumed to be equal to the solid surface temperatures. This assumption results in a zero entropy generation at internal heat transfer processes, and the thermodynamic cycle becomes internally reversible. Therefore, the isothermal nodal model does not provide data about the thermal efficiency of the engine.

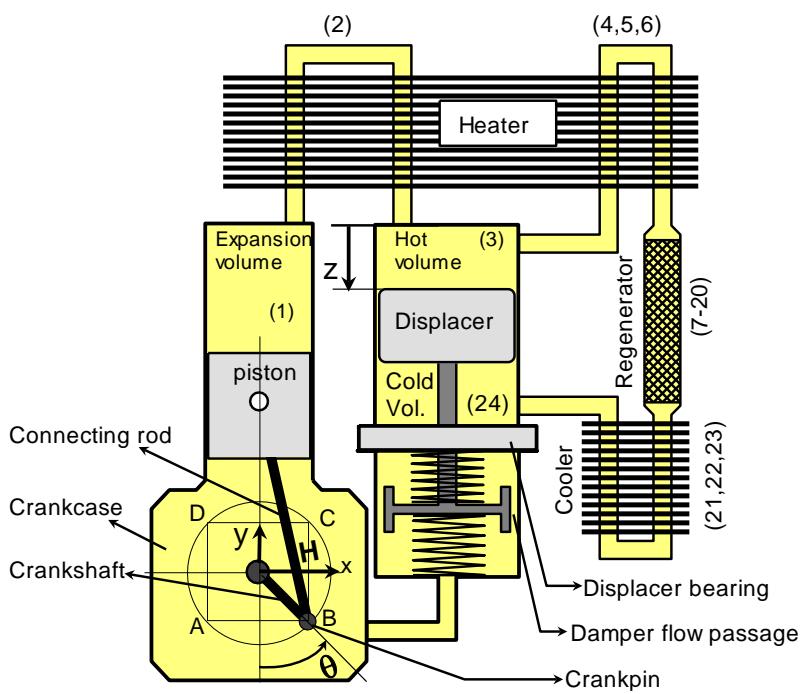

Figure 1. Schematic view of the free displacer engine (Karabulut et al, 2020).

In this study, a combined thermodynamic and dynamic analysis of free displacer Stirling engines has been conducted. The main difference of this study from the paper of Karabulut et al. (Karabulut et al, 2020) is that the gas force applied on the power piston and displacer is calculated via a polytrophic nodal analysis where the gas temperature in nodal volumes is calculated with the first law of the thermodynamic differently from isothermal nodal analysis. In isothermal nodal analysis, as explained above, the gas temperatures in nodal volumes are assumed to be equal to the solid temperatures surrounding the nodal volumes. The combined thermodynamic and dynamic analysis conducted in this study enables the prediction of heat transfer areas in the heater, cooler and regenerator as well as providing data about the thermal performance parameters of the engine. The analysis presented in this study provides also more realistic data about the dynamic behavior of the engine such as oscillation amplitude of the displacer and stable working conditions of the engine.

\section{ELEMENTS OF THE MECHANISM AND WORKING PROCEDURE}

Figure 1 illustrates schematic view of the free displacer engine (Karabulut et al, 2020). The engine consists of two principal sections as work generation and heat transfer modules. The work generation unit involves a crankshaft, a crankcase, a cylinder, a piston and its connecting rod. The heat transfer module involves a displacer and its cylinder, an axial rod bearing for displacer rod, a heater, a cooler, a regenerator, a spring, a damper and a room for displacer spring. The spring room is a cylindrical cavity. The pressure in the spring room is equated to the crankcase pressure by connecting the spring room to the crankcase with a pipe. The regenerator is a tub filled with porous material. The heater and cooler are flow passages filled with porous material as well. The damper may be built by mounting a perforated disc or a piston to the end of displacer rod. While the perforated disc or the piston is performing reciprocal motion in spring room, the gas in the spring room performs reciprocating flow through narrow flow channels and generates a damping force acting to displacer. The flow resistance appearing in the heater regenerator and cooler may also generate adequate damping force to stabilize the motion of the displacer.

The working procedure of the engine could be described by means of the crankshaft rotation diagram shown in Fig. 1 where, $360^{\circ}$ rotation of the crankshaft is divided into 4 sections. As crankpin is moving from $B$ to $C$, the displacer stays at upper end of the displacer cylinder. The piston moves upwards and sweeps the working substance from the expansion cylinder to the cold compartment of the displacer cylinder through the heater, regenerator and cooler. When this process is ended, the bulk of working fluid becomes compressed in the cold compartment of the displacer cylinder. While the crankpin is moving from $\mathrm{C}$ to $\mathrm{D}$, the piston stays at the top dead center. The displacer moves down and sweeps the compressed working substance from the cold compartment to the hot compartment through the cooler, regenerator and heater. When this process ended, the temperature of the compressed gas becomes increased. The pressure of the gas is at the highest level of the thermodynamic cycle. While the crankpin is moving from $\mathrm{D}$ to $\mathrm{A}$, the displacer stays at the lower end of the cylinder. The piston moves from up to down and the hot gas in the hot compartment of the displacer cylinder expands into the expansion cylinder and generates work. As the crankpin is moving $\mathrm{B}$, the piston stays almost at the bottom dead center of its stroke. The volume of the expansion cylinder remains unchanged. The displacer moves up and sweeps the gas from hot compartment to the cold compartment. When this process ended, the bulk temperature of the gas in the 
working space of the engine becomes relatively lower. As a result of lower bulk temperature, the gas pressure in the working space decreases to its lowest value and becomes ready for a new cycle. According to this working procedure of the free displacer Stirling engine, the down motion of the displacer occurs $90^{\circ}$ before the down motion of the piston in terms of crankshaft angle. This difference is named as phase angle.

\section{MATHEMATICAL MODEL}

The mathematical model used in this study is a combination of a thermodynamic model and a dynamic model (Karabulut et al, 2020). The thermodynamic model consists of the first law of the thermodynamic, the perfect gas relation, the pressure formulae of Schmidt and kinematic formulations describing hot volume, cold volume and expansion cylinder volume. The thermodynamic model used in this study provides an opportunity to increase the number of nodal volumes in the heater, cooler and regenerator as desired. The dynamic model used in this study possesses two degrees of freedom such as freedom for the crankshaft mechanism and freedom for the displacer. The dynamic model consists of the movement equation of the displacer, the movement equation of the crankshaft and the movement equation of the power piston. The movement equation of the connecting rod was excluded from the analysis by increasing the piston mass about 30 $\%$ of the connecting rod mass. The independent variable of the analysis is time $(t)$. The principal dependent variables are displacer location $(z)$ and crankshaft angle $(\theta)$. The location of the piston ( $y$ ) is kinematically related to $\theta$ and it is not a principal dependent variable.

The displacer performs an oscillatory motion under the influence of forces illustrated in Figure 2, which are; the gas force $A_{R}\left(p_{w}-p_{c h}\right)$, spring force $k\left(z-z_{0}\right)$ and damping force $c \dot{z}$. The damping forces are caused by the displacer damper as well as the viscous friction around the displacer rod and the flow resistances appearing in regenerator and connecting pipes. The damping coefficient $c$ involves the contributions of all of these factors. The movement equation of the displacer is derived according to the local coordinate axis illustrated in Figure 2. The movement equation of the displacer is

$$
m \ddot{z}+c \dot{z}+k\left(z-z_{0}\right)=A_{R}\left(p_{w}-p_{c h}\right)
$$

where $\dot{z}$ and $\ddot{z}$ indicate the instantaneous velocity and acceleration of the displacer.

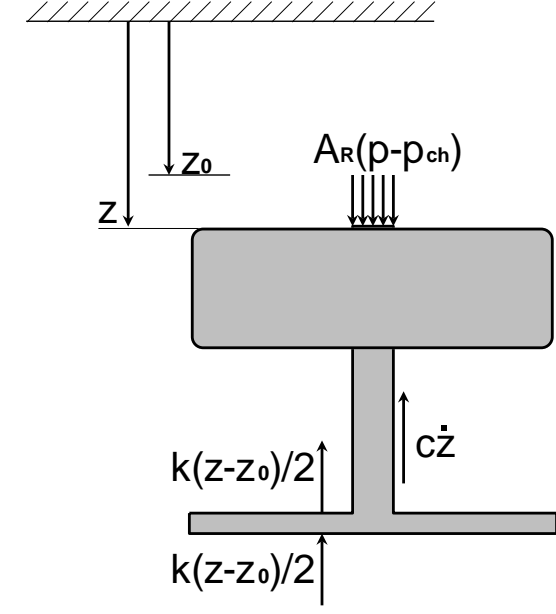

Figure 2. Forces acting on the displacer.

The forces considered in the establishment of movement equation of the piston are the gas force acting on the piston top $\left(F_{w}\right)$, the gas force acting to the down surface of the piston $\left(F_{c h}\right)$, the connecting rod force $\left(F_{b}\right)$, the frictional force generated by the piston rings $\left(F_{\infty}\right)$, the force generated by the solid contact friction at the piston side surface $\left(\sigma F_{b x}\right)$ and the force generated by the hydrodynamic friction at side surface of the piston $\left(C_{p} \dot{y}\right.$

). The piston ring force $\left(F_{\infty}\right)$ and the solid contact friction force $\left(\sigma F_{b x}\right)$ are Coulomb type force. The forces acting on the piston and the local coordinate system used in the derivation of the movement equation of the piston are illustrated in Figure 3.

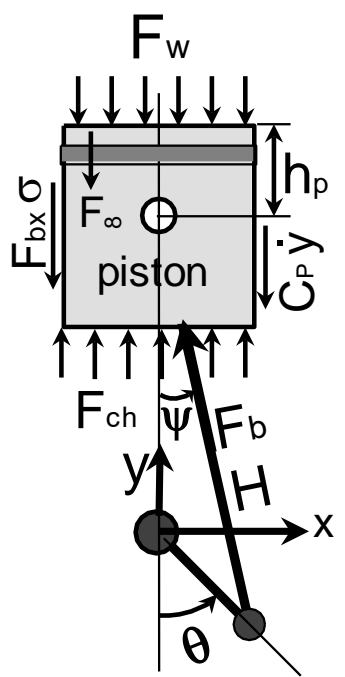

Figure 3. Forces acting on the piston.

The movement equation of the piston is

$$
\begin{aligned}
m_{p} \ddot{y}+C_{p} \dot{y}= & F_{b} \cos \psi+F_{c h}-F_{w}- \\
& F_{\infty} \operatorname{sgn}(\dot{y})-\left|\sigma F_{b x}\right| \operatorname{sgn}(\dot{y})
\end{aligned}
$$

In the last equation $\psi, \dot{y}$ and $\ddot{y}$ indicate respectively the angle between the connecting rod and $y$ axis, the velocity of the piston and the acceleration of the piston. 
From the Equation (2), the force of connecting rod is defined as

$$
\begin{aligned}
F_{b}= & \frac{m_{p} \ddot{y}+F_{w}-F_{c h}+C_{p} \dot{y}}{\cos \psi}+ \\
& \frac{F_{\infty} \operatorname{sgn}(\dot{y})+\left|\sigma F_{b x}\right| \operatorname{sgn}(\dot{y})}{\cos \psi}
\end{aligned}
$$

In the last equation the numerator is equal to the vertical component of the force vector exerted by the connecting rod to the crankpin. According to the $x, y$ coordinate system indicated in Figure 1, the force vector applied by the connecting rod to the crankpin is defined as

$$
\begin{aligned}
\vec{F}_{b c}= & \left(F_{b} \sin \psi\right) i- \\
& {\left[\begin{array}{l}
m_{p} \ddot{y}+F_{w}-F_{c h}+C_{p} \dot{y}+ \\
F_{\infty} \operatorname{sgn}(\dot{y})+\left|\sigma F_{b x}\right| \operatorname{sgn}(\dot{y})
\end{array}\right] j }
\end{aligned}
$$

The moment rotating the crankshaft is generated by the force vector defined by the last equation. The crank radius $(R)$ is the moment arm of this force vector. Considering the coordinate system indicated in Figure 1, the vector form of the moment arm is defined as

$$
\vec{R}=R \sin \theta i-R \cos \theta j
$$

By performing the vector product of the vectors given by the last two equations, the moment rotating the crankshaft is determined as

$$
\begin{aligned}
M_{c}= & (-\sin \theta+\cos \theta \operatorname{tg} \psi) R \\
& {\left[\begin{array}{l}
m_{p} \ddot{y}+F_{w}-F_{c h}+C_{p} \dot{y}+ \\
\left(F_{\infty}+\left|\sigma F_{b x}\right|\right) \operatorname{sgn} \dot{y}
\end{array}\right] }
\end{aligned}
$$

In the derivation of the movement equation of the crankshaft, the moment defined with Equation (6), the moment of the main journal viscous friction $\left(C_{m j} \dot{\theta}\right)$, the moment of the crankpin viscous friction $\left(C_{k m} \dot{\theta}\right)$, the moment of the starter motor $\left(M_{s}\right)$ and the external load applied to the engine $\left(M_{q}\right)$ are considered. The movement equation of the crankshaft may be written as

$$
\ddot{\theta}=\frac{M_{c}}{I}+\frac{M_{s}-M_{q}}{I}-\frac{C_{m j}}{I} \dot{\theta}-\frac{C_{k m}}{I}(\dot{\theta}-\dot{\psi})
$$

The external load $\left(M_{q}\right)$ may be considered to be generated by an electrical or hydrodynamic tork generator and defined as

$$
M_{q}=C_{q} \dot{\theta}
$$

The velocity and acceleration of the piston, taking part in above equations, vary with the position angle of the crankshaft ( $\theta)$ and obtained from the kinematic relation defining the position of the piston top in terms of $\theta$. According to the coordinate system seen in Figure 3, the position of the piston top is defined as

$$
y=-R \cos \theta+H \cos \psi+h_{p}
$$

where $H$ and $h_{p}$ were shown in Figure 3. The velocity and acceleration of the piston are

$$
\begin{array}{r}
\dot{y}=R \sin \theta \dot{\theta}-H \sin \psi \dot{\psi} \\
\ddot{y}=R \cos \theta \dot{\theta}^{2}+R \sin \theta \ddot{\theta}- \\
\quad H \cos \psi \dot{\psi}^{2}-H \sin \psi \ddot{\psi}
\end{array}
$$

The angular speed $(\dot{\psi})$ and acceleration $(\ddot{\psi})$ of the connecting rod are obtained from

$$
\psi=\arcsin \left(\frac{R}{H} \sin \theta\right)
$$

which are not presented here for the brevity of the paper.

The Schmidt formula was used to calculate the engine inner pressure. In this analysis the pressure difference between the nodal volumes due to flow friction is disregarded. The inner volume of the mechanism was divided into 24 nodal volumes. The first of the nodal volumes is the expansion volume seen in Figure 1. The second of the nodal volumes is the volume of a pipe connecting the expansion volume to the displacer cylinder. The third of nodal volumes is the hot end volume of the displacer cylinder which is a periodically varying volume. Nodal volumes 4,5 and 6 take part in heater. Nodal volumes 7-20 take part in regenerator. Nodal volumes 21, 22 and 23 take part in cooler. The nodal volume 24 is the cold end volume of the displacer cylinder which is a varying volume as well. For a nodal analysis with 24 volumes Schmidt formula is written as

$$
p_{w}=\frac{m \Re}{\sum_{n=1}^{n=24} \frac{V_{n}}{T_{n}}}
$$

Within a time step, the variation of gas temperature in a nodal volume ( $\Delta T)$ may be calculated with the first law of thermodynamics.

By canceling the kinetic energy, potential energy and heat generation terms, the first law is written as

$$
\Delta Q-\Delta W=\left(m_{o} h_{o}\right)-\left(m_{i} h_{i}\right)+(\Delta U)
$$

In this equation $\Delta Q, \Delta W, \Delta U,\left(m_{o} h_{o}\right)$ and $\left(m_{i} h_{i}\right)$ indicate nodal values of the heat exchange, work generation, internal energy variation, outflow of enthalpy 
and inflow of enthalpy. By using the definitions $\Delta Q=\alpha A_{v}\left(T_{w}-T\right) \Delta t$, $\Delta W=p \Delta V$ $\Delta U=m C_{v} \Delta T+C_{v} T \Delta m, m_{o} h_{o}=H_{o}$ and $m_{i} h_{i}=H_{i}$, Equation (14) is transformed to

$$
\begin{aligned}
\alpha A_{v}\left(T_{w}-T\right) \Delta t-p_{w} \Delta V= & H_{o}-H_{i}+ \\
& m C_{v} \Delta T+C_{v} T \Delta m
\end{aligned}
$$

By adding $\Omega \Delta T$ to both sides of the last equation and then solving for $\Delta T$ results in

$$
\Delta T=\left[\begin{array}{l}
\alpha A_{v}\left(T_{w}-T\right) \Delta t- \\
p_{w} \Delta V+\left(H_{i}-H_{o}\right)- \\
C_{v} T \Delta m+\Omega \Delta T
\end{array}\right] /\left(m C_{v}+\Omega\right)
$$

The temperature variation in nodal volumes during time steps is calculated with the above form of the first law. In this equation, the difference between inflowing and outflowing enthalpies is calculated with

$$
\begin{aligned}
\left(H_{i}-H_{o}\right)=-C_{p} \frac{T_{n-1}+T_{n}}{2}\left[\begin{array}{l}
\left(m_{1}-m_{1}^{F}\right)+ \\
\left(m_{2}-m_{2}^{F}\right)+ \\
\ldots+\left(m_{n-1}-m_{n-1}^{F}\right)
\end{array}\right] \\
-C_{p} \frac{T_{n}+T_{n+1}}{2}\left[\begin{array}{l}
\left(m_{n+1}-m_{n+1}^{F}\right)+ \\
\left(m_{n+2}-m_{n+2}^{F}\right)+ \\
\ldots+\left(m_{24}-m_{24}^{F}\right)
\end{array}\right]
\end{aligned}
$$

In the last equations, the superscript $F$ indicates the time-step before the current one. For the current time step, gas temperatures in cells are calculated as

$$
T=T^{F}+\Delta T
$$

The gas masses in cells are calculated with the state equation of the perfect gasses, which is

$$
m=\frac{p_{w} V}{\mathfrak{R} T}
$$

The instantaneous values of the expansion volume (1), hot volume (3) and cold volume (24) are simply formulated by using kinematic relations which are not given here to sake the brevity of the analysis.

The solution of the equations (1) and (7) in time domain requires two boundary conditions for each. The appropriate boundary conditions are $t=0, \quad z=0, \quad \dot{z}=0, \quad \theta=0, \dot{\theta}=0$. To initiate the solution process, the initial pressure in the refrigerator, the initial gas temperatures in cells and initial gas masses in cells are needed. For initial gas temperatures in cells, values equal to the wall temperatures of cells may be introduced. So, the initial pressure in the engine is able to be calculated with equation (13). The initial values of nodal masses can be calculated with Equation (19). After the determination of all initial values, the calculation of unknowns at subsequent time steps are conducted. For numerical procedure, readers may refer to the reference (Karabulut et al, 2020; Altin et al, 2018; Karabulut et al, 2019).

\section{Inputs Used In the Analysis}

In this study, the solid surface temperatures of the heater, cooler, expansion cylinder and displacer cylinder are assumed to be pre-known values. The distribution of matrix temperature in the regenerator is also assumed to be a pre-known. Figure 4 indicates the temperature of solid surfaces and regenerator matrix.

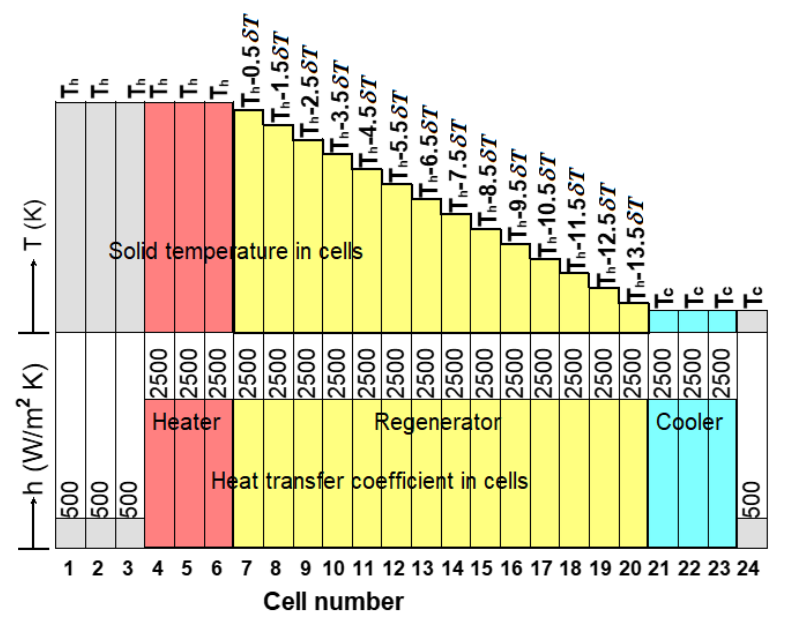

Figure 4. Solid surface temperature and heat transfer coefficient in cells of the engine.

Figure 4 also indicates the distribution of the heat transfer coefficient in cells of the engine. The heat transfer coefficient in the regenerator has been used from Tanaka and coworkers (Tanaka et al, 1990). The heat transfer coefficients in cooler and heater were taken to be equal to that in the regenerator matrix because the cooler and heater were assumed to be flow passages filled with porous material. The heat transfer coefficient of expansion and displacer cylinders were predicted via theoretical approximations. Specific values and inputs used in the analysis are presented in Table 1. Specific values were determined by aiming an engine able to provide $3 \mathrm{~kW}$ or more power.

\section{RESULT AND DISCUSSION}

The robustness of the results depends on the magnitude of time steps and rotation number of the engine from starting instant. The time step has influences on the precision of numerical results as well as the robustness of work calculation with numerical integration. The magnitude of time steps was determined to be $0.00001 \mathrm{~s}$ by trial and error. The rotation number of the engine is related to obtaining steady running conditions of the engine. Unless the rotation number of the engine reaches to a certain value, the calculated parameters involves the 
influence of initial condition. If the engine rotates about 300 revolutions, steady state conditions are reached.

Table 1. Specific values and inputs used in the analysis

\begin{tabular}{|l|l|}
\hline Specific values and inputs & $\begin{array}{l}\text { Numerical } \\
\text { value }\end{array}$ \\
\hline $\begin{array}{l}\text { Torsional damping constant of } \\
\text { crankshaft main bearings }(\mathrm{N} s \mathrm{~m} / \mathrm{rad})\end{array}$ & 0.00019 \\
\hline $\begin{array}{l}\text { Torsional damping constant of } \\
\text { crankshaft connecting rod bearing } \\
(\mathrm{Nsm} / \mathrm{rad})\end{array}$ & 0.00012 \\
\hline Damping constant of piston $(\mathrm{Ns} / \mathrm{m})$ & 2.0 \\
\hline Coulomb friction coefficient of piston & 0.04 \\
\hline Crosscut area of displacer cylinder $\left(\mathrm{m}^{2}\right)$ & $100 / 10000$ \\
\hline Piston mass $(\mathrm{kg})$ & 1.5 \\
\hline $\begin{array}{l}\text { Crosscut area of expansion cylinder } \\
\left(m^{2}\right)\end{array}$ & $100 / 10000$ \\
\hline Working substance & Helium \\
\hline Crank radius $(\mathrm{m})$ & 0.04 \\
\hline Piston connecting rod length $(m)$ & 0.16 \\
\hline $\begin{array}{l}\text { Total stroke length of the displacer } \\
\text { cylinder }(m)\end{array}$ & 0.09 \\
\hline Regenerator heat transfer area $\left(m^{2}\right)$ & 5 \\
\hline Regenerator porosity & 0.7 \\
\hline Regenerator total volume $\left(m^{3}\right)$ & $1.04166 / 1000$ \\
\hline Dead volume in regenerator $\left(m^{3}\right)$ & $7.29166 / 10000$ \\
\hline Heater heat transfer area $\left(m^{2}\right)$ & 1.5 \\
\hline Heater temperature, $T_{h},(K)$ & 1000 \\
\hline Dead volume in heater $\left(m^{3}\right)$ & $2.1875 / 10000$ \\
\hline Cooler heat transfer area $\left(m^{2}\right)$ & 1.5 \\
\hline Cooler temperature, $T_{c},(K)$ & 356 \\
\hline Dead volume in cooler $\left(m^{3}\right)$ & $2.1875 / 10000$ \\
\hline $\begin{array}{l}\text { Average heat transfer area in expansion } \\
\text { cylinder }\left(m^{2}\right)\end{array}$ & $400 / 10000$ \\
\hline $\begin{array}{l}\text { Average heat transfer area in hot } \\
\text { compartment of displacer cylinder }\left(m^{2}\right)\end{array}$ & $300 / 10000$ \\
\hline $\begin{array}{l}\text { Average heat transfer area in cold } \\
\text { compartment of displacer cylinder }\left(m^{2}\right)\end{array}$ & $300 / 10000$ \\
\hline
\end{tabular}

\section{Dynamic Behaviors of the Engine}

In the Stirling engine examined here, the vibration of the displacer is governed by several parameters such as, engine pressure variation, the crosscut area of the displacer rod, the spring constant, the mass of displacer itself and the damping force exerting on displacer etc. To run a free displacer Stirling engine, the power piston should make a reciprocational motion at a frequency equal to the displacer system natural frequency. When the engine is rotated via a starter motor, the working gas pressure in the engine performs periodic variations. Because of periodically varying pressure, the displacer tends to make vibrational motions. If the frequency of the pressure variation increases to the displacer system natural frequency, the amplitude of the vibrational motion of the displacer increases to an adequate magnitude and causes the working gas to displace between the hot and cold compartments. While the piston and displacer are performing up and down periodic motions, the inertia of the displacer generates a phase angle and enables heating, expansion, cooling and compression processes.
Unless the piston frequency increases to the displacer system natural frequency, the engine does not run. Therefore, a high speed starter motor is needed, to start free displacer Stirling engines.

Another dynamic problem of the free displacer Stirling engine is running irregularities named beating. Beating is some periodic increases and decreases in the stroke length of the displacer. Due to beating, the work generation of the engine exhibits some increases and decreases. Beating may be minimized but not eliminated completely. If there is a certain equilibrium between the spring constant, mass of oscillating object and damping constant of the system; beating becomes small enough. In oscillating linear systems, the equilibrium between the spring constant, damping constant and mass of the oscillating system may be treated analytically, but the free displacer Stirling engine is not a linear system. In free displacer Stirling engines, the minimization of beating requires an interactive process via a simulation program.

Table 2 indicates an optimized set of interactive parameters corresponding to $160000 \mathrm{~N} / \mathrm{m}$ spring stiffness. Figure 5 indicates the variation of displacer position with crankshaft angle for a non-optimized set of working parameters. Data used in Figure 5 were obtained by using the optimized set of working parameters given in Table 2 except the mass of the displacer. The mass of the displacer was taken to be $1.75 \mathrm{~kg}$. As shown in Figure 5 , the amplitude of the displacer motion exhibits some increases and decreases. This variation of the displacer amplitude repeats itself periodically over a certain number of engine cycles or, in a certain interval of crankshaft angle. Figure 6 indicates some sequential PV diagrams of the engine which were obtained also with $1.75 \mathrm{~kg}$ displacer mass and interactive parameters given in Table 2. As seen from Figure 6, the PV diagrams are varying from cycle to cycle.

Table 2. An optimized set of interactive parameters determined for $160000 \mathrm{~N} / \mathrm{m}$ spring stiffness.

\begin{tabular}{|l|l|}
\hline Interactive parameters & $\begin{array}{l}\text { Numerical } \\
\text { value }\end{array}$ \\
\hline Spring constant $(\mathrm{N} / \mathrm{m})$ & 160000 \\
\hline $\begin{array}{l}\text { Torsional damping constant of the } \\
\text { dynamometer }(\mathrm{Nsm} / \mathrm{rad})\end{array}$ & 0.03 \\
\hline $\begin{array}{l}\text { Damping constant of displacer rod } \\
(\mathrm{Ns} / \mathrm{m})\end{array}$ & 15.0 \\
\hline Crosscut area of displacer rod $\left(\mathrm{m}^{2}\right)$ & $6 / 10000$ \\
\hline Working gas mass $(\mathrm{kg})$ & 0.0065 \\
\hline Displacer mass $(\mathrm{kg})$ & 1.722 \\
\hline Static position of displacer top, $x_{0},(\mathrm{~m})$ & 0.05 \\
\hline $\begin{array}{l}\text { Mass moment of inertia of the crankshaft } \\
\left(\mathrm{m}^{2} \mathrm{~kg}\right)\end{array}$ & 0.1 \\
\hline
\end{tabular}




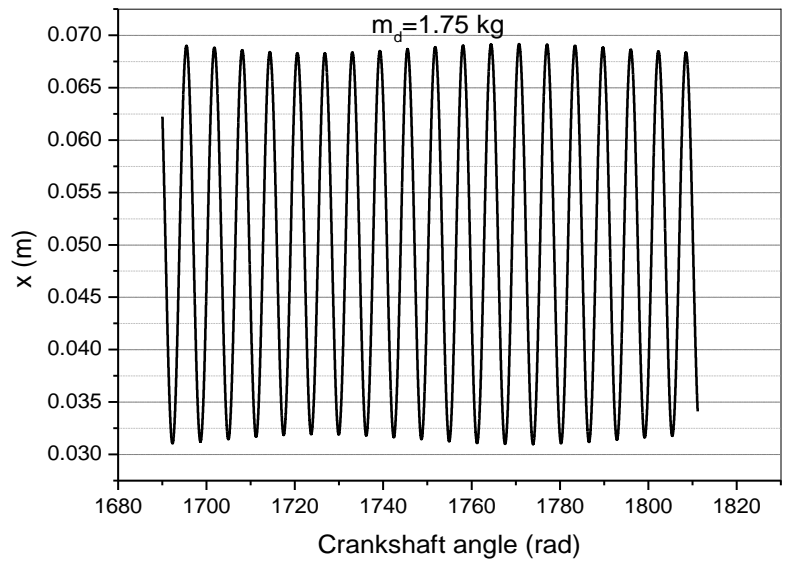

Figure 5. Variation of displacer position with time for optimized inputs.

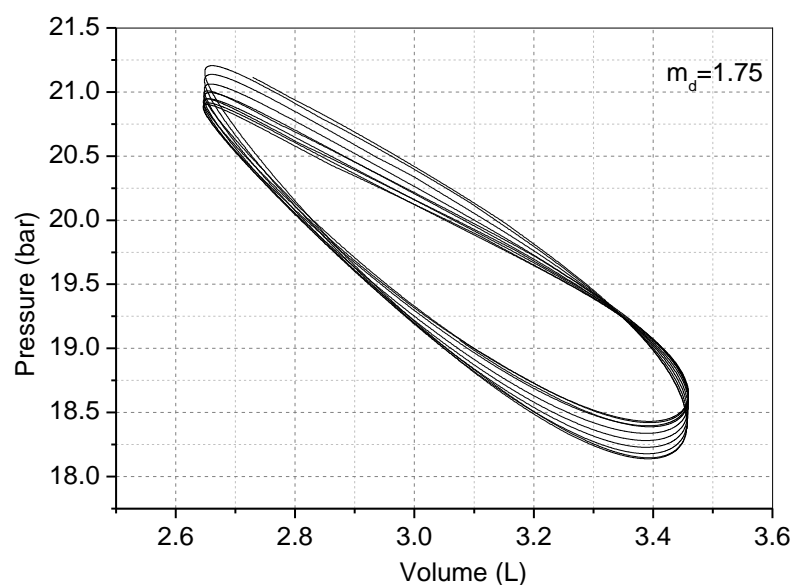

Figure 6. Sequential PV diagram obtained for optimized inputs excluding displacer mass.

In simulation program, in case of setting $1.722 \mathrm{~kg}$ displacer mass, which is given in Table 2, beating becomes insignificant and variations of the work and other thermodynamic values from cycle to cycle are avoided. Figure 7 indicates variation of the displacer position with crankshaft angle while Figure 8 is indicating a number of sequential PV diagrams. As seen in Figure 7, the displacer motion exhibits no visible beating. According to Figure 8, the overlap of PV diagrams is quite good.

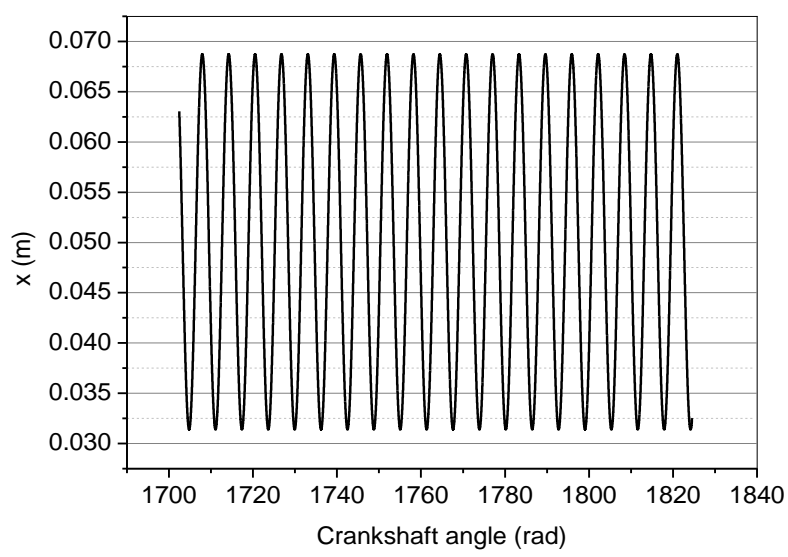

Figure 7. Variation of the displacer position with time.

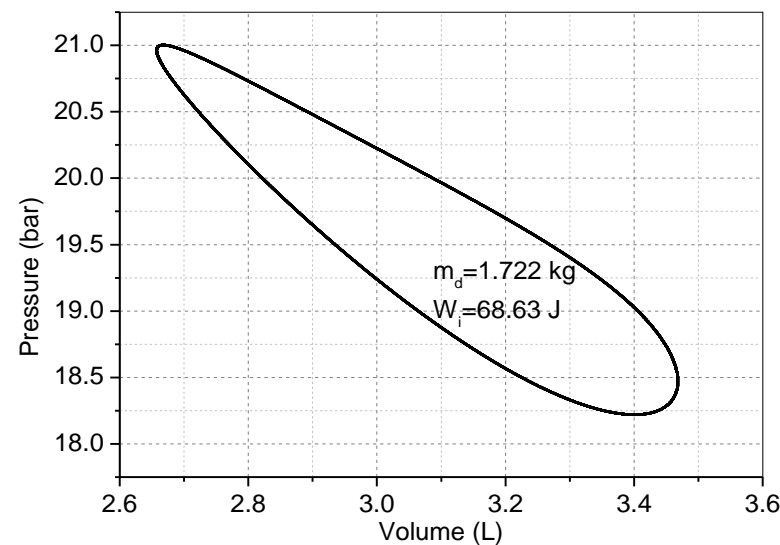

Figure 8. PV diagram obtained for inputs in Table 1 and 2.

\section{Examination of the Engine Performance with Respect to Displacer Mass}

In free displacer Stirling engines, one of the principal parameters having influence on the working performance of the engine is the displacer mass. In this examination, by using the inputs given in Table 2 and by introducing different values for the displacer mass, results presented in Table 3, in Figure 9 and in Figure 10 were obtained. At $1.353 \mathrm{~kg}, 1.47 \mathrm{~kg}, 1.589 \mathrm{~kg}, 1.722 \mathrm{~kg}$ and $1.87 \mathrm{~kg}$ values of the displacer mass, very robust results were obtained. Just under $1.353 \mathrm{~kg}$, and just over $1.87 \mathrm{~kg}$, the engine keeps working, but overlapping of the sequential PV diagrams becomes imperfect. If the displacer mass is further decreased after giving an initial motion to the engine via the starter motor, it does not continue to run and gradually goes to stop. In case the displacer mass increases further, it performs steadily increasing strokes and goes out of stabile working. The most perfect overlapping of the sequential PV diagrams occurs at some certain values of the displacer mass, which are given in the Table 3. Between these values of the displacer mass, the overlapping of the sequential PV diagrams is poor. In Table 3, Figure 9 and Figure 10, it is seen that as the displacer mass is decreasing, the performance parameters of the engine (torque, speed, thermal efficiency and power) become profoundly better although the heat exchanges between the working fluid and heat sources are almost the same. Therefore, the increase in engine performance is not relevant to the heat exchange rates between working fluid and heat sources. As seen in Table 3, while the displacer mass is decreasing from $1.87 \mathrm{~kg}$ to $1.353 \mathrm{~kg}$, the phase angle between the piston and displacer varies from $120^{\circ}$ to $103^{\circ}$. In most of the kinematic engine, the highest performance appears at about $90^{\circ}$ phase angle. This situation implies that the increase of the engine performance is mainly raised due to the phase angle variation.

In Table 3, it is seen that the indicated thermal efficiency of the engine varies between $23.7 \%$ and $27.7 \%$. For the working temperature limits of the current engine, the Carnot efficiency is about $64 \%$. The big difference between these thermal efficiencies is caused by insufficient circulation of the working fluid between the hot and cold compartments of the displacer cylinder. In 
this engine, as seen in Table 3, the stroke of the displacer varies between $36.7 \mathrm{~mm}$ and $37.89 \mathrm{~mm}$ although that the displacer cylinder length is $90 \mathrm{~mm}$. This indicates that more than half of the working fluid contained by the displacer cylinder is left out of circulation. As a result of this disadvantage, the thermal efficiency of the free displacer engines becomes too lower than the Carnot efficiency.

While the displacer mass is decreasing, the natural frequency of the displacer system increases consistently with the nature of the vibrating systems. As a result of this phenomenon, the speed of the engine performs an accelerating increase as shown in Figure 10. As the displacer mass is decreasing, the torque of the engine increases as well. The increase of the torque is likely to be related to the variation of the phase angle. As a result of the increase in engine speed and torque, the indicated power and effective power exhibit better increase as shown in Figure 10. The mechanical efficiency of the engine $\left(\boldsymbol{P}_{\boldsymbol{e}} / \boldsymbol{P}_{\boldsymbol{i}}\right.$ ) varies between $83.7 \%$ and $80.6 \%$. The highest values of the indicated power and effective power are 4394 and $3588 \mathrm{~W}$ respectively. The density of indicated power of the engine is about $1275 \mathrm{~W} / \mathrm{L}$. At $1.353 \mathrm{~kg}$ displacer mass, and the engine provides the highest performance parameters. A displacer mass of $1.353 \mathrm{~g}$ is found to be appropriate for manufacturing as well.

Table 3. Variation of performance parameters with respect to the displacer mass.

\begin{tabular}{|c|c|c|c|c|c|c|c|c|c|c|c|c|}
\hline $\begin{array}{c}m_{d} \\
(\mathrm{~kg})\end{array}$ & $\begin{array}{c}\omega \\
(\mathrm{rad} / \mathrm{s})\end{array}$ & $\begin{array}{c}\bar{M}_{q} \\
(\mathrm{Nm})\end{array}$ & $\begin{array}{c}W_{i} \\
(\mathrm{~J})\end{array}$ & $\begin{array}{c}W_{Q} \\
(\mathrm{~J})\end{array}$ & $\begin{array}{c}Q_{h} \\
(\mathrm{~J})\end{array}$ & $\begin{array}{c}Q_{c} \\
(\mathrm{~J})\end{array}$ & $\begin{array}{c}\eta_{e} \\
(\%)\end{array}$ & $\begin{array}{c}\eta_{i} \\
(\%)\end{array}$ & $\begin{array}{c}P_{e} \\
(W)\end{array}$ & $\begin{array}{c}P_{i} \\
(W)\end{array}$ & $\begin{array}{c}\phi \\
(\mathrm{deg})\end{array}$ & $\begin{array}{c}s \\
(\mathrm{~mm})\end{array}$ \\
\hline 1.353 & 345.81 & 10.375 & 79.84 & 80.80 & 288.6 & 207.8 & 0.2258 & 0.2766 & 3587.6 & 4394.1 & 103 & 36.70 \\
\hline 1.47 & 329.72 & 9.892 & 74.20 & 72.79 & 292.1 & 219.3 & 0.2128 & 0.2540 & 3261.5 & 3893.5 & 109 & 36.90 \\
\hline 1.589 & 316.03 & 9.482 & 71.26 & 69.57 & 292.2 & 222.7 & 0.2038 & 0.2438 & 2996.5 & 3584.0 & 113 & 37.08 \\
\hline 1.722 & 303.60 & 9.108 & 68.63 & 67.45 & 291.0 & 223.5 & 0.1967 & 0.2359 & 2765.1 & 3316.2 & 117 & 37.28 \\
\hline 1.87 & 295.45 & 8.863 & 69.11 & 68.40 & 291.8 & 223.1 & 0.1908 & 0.2368 & 2618.6 & 3249.7 & 120 & 37.89 \\
\hline
\end{tabular}

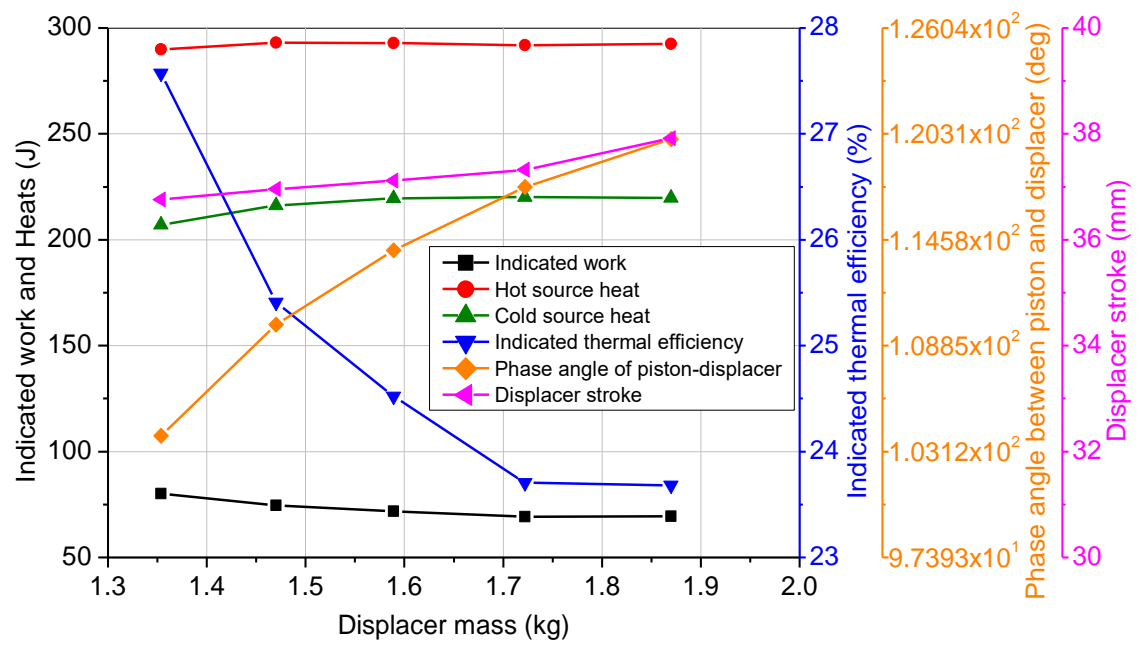

Figure 9. Variations of indicated work, heats, thermal efficiency, phase angle and stroke.

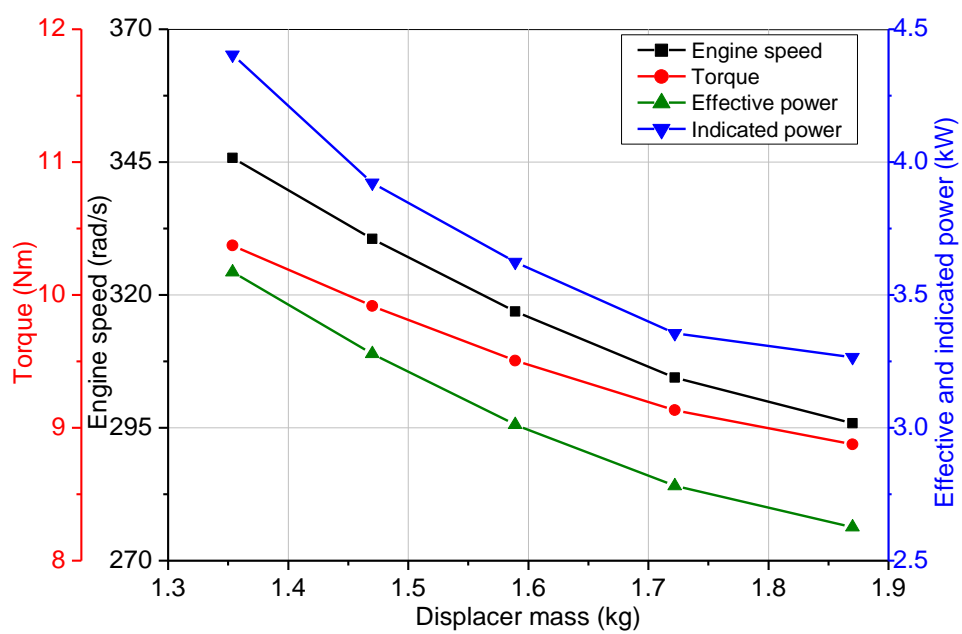

Figure 10. Variations of speed, torque and power with displacer mass. 
Examination of the Engine Performance with Respect to Working Gas Mass

In Stirling engines, the only way to increase specific power is to increase the mass of the working fluid. The appropriate amount of the working fluid to be charged is determined by optimizing the performance parameters of the engine with respect to the working fluid mass. In this examination, excluding the working fluid mass and spring stiffness, all of the inputs were kept constant. The working fluid mass was varied between $6.5 \mathrm{~g}$ and $4.75 \mathrm{~g}$. Therefore, in the above examination the highest performances were obtained at $1.353 \mathrm{~kg}$ displacer mass, and the mass of displacer was taken to be $1.353 \mathrm{~kg}$. As the working fluid mass was varying, at some values of the spring stiffness, the sequential PV diagrams become overlapped and robust performance data are obtained. Appropriate values of the spring stiffness that meet the overlapping condition of PV diagrams are presented in Table 4, as well as the performance parameters of the engine. Figure 11 and Figure 12 illustrate the variations of the performance parameters with respect to working fluid mass. As seen in Figure 11 and Table 4, while the gas mass is varying from $4.75 \mathrm{~g}$ to $6.5 \mathrm{~g}$, the speed displays a decelerating increase from $295 \mathrm{rad} / \mathrm{s}$ to 338 $\mathrm{rad} / \mathrm{s}$. In essence, the relation between the working fluid mass and speed is an indirect relation as the speed is dependent on the displacer system natural frequency. Therefore, the reel cause of the speed variation is the variation of the spring stiffness. As shown in Figure 11, the variation of the torque with the working fluid mass is also a decelerating increase. While the mass of working fluid is varying from $4.75 \mathrm{~g}$ to $6.5 \mathrm{~g}$, the torque varies from $8.832 \mathrm{Nm}$ to $10.15 \mathrm{Nm}$. The variation of the torque profile is related to the temperature limits of the thermodynamic cycle as well as frictional losses. While the mass of the working fluid increases, inherently its heat storage capacity increases as well. Due to the larger heat storage capacity of the working fluid, the difference between the upper and lower limits of the temperature of the cycle becomes narrow. The increasing speed of the engine has also some effects on narrowing the temperature difference of the thermodynamic cycle thereby reducing the heat exchange time. As a result of narrowing temperature difference, the torque becomes lower inherently. It is also inherent that the higher working fluid mass is higher working fluid pressure and higher frictional losses. As seen in Figure 11, the effective and indicated powers display decelerating increases in working fluid mass as well. The reason for this deceleration is again the narrowing temperature difference of the cycle. In Figure 11 and Table 4, it is seen that the effective thermal efficiency of the engine performs an accelerating decrease with working fluid mass. This is caused by weakening heat exchanges due to decreasing heat exchange time and narrowing temperature difference of the cycle as well.

As the gas mass is increasing from $4.75 \mathrm{~g}$ to $6.5 \mathrm{~g}$, the indicated work exhibits a decelerating increase as shown with the black line in Figure 12. About $6.5 \mathrm{~g}$ working fluid mass, the increase in indicated work seems to be terminating. This is related to the temperature limits of the thermodynamic cycle as well as the minimal variation of the phase angle. Within the examined range of the mass of working fluid, as the gas mass is increasing, the hot source heat and cold source heat increase respectively from $221 \mathrm{~J}$ to $290 \mathrm{~J}$ and from $158 \mathrm{~J}$ to $213 \mathrm{~J}$. Both the hot source and the cold source heats are varying almost linear. In Stirling engines, the heat transfer in the heater is not always from solid to fluid. The heat transfer in the cooler is also not always from fluid to solid. The heat exchange in the regenerator has also a complicated mechanism. Therefore, the work calculated with $W_{Q}=Q_{h}-Q_{c}$ may not be very robust. In this analysis the work calculated with $d W=P d V$ is assumed as the correct value of the indicated work. Within the examined limits of the working fluid mass, the variation of the phase angle and displacer stroke are 1 degree and $0.6 \mathrm{~mm}$ respectively. As the working fluid mass is increasing, the indicated thermal efficiency exhibits an increasing and decreasing trend. The maximum value of the indicated thermal efficiency appears at about $5 \mathrm{~g}$ working fluid mass as $29.35 \%$. Above $5 \mathrm{~g}$ mass, the indicated thermal efficiency presents an accelerating decrease. The cause of this accelerating decrease is the narrowing temperature difference of the thermodynamic cycle. $5 \mathrm{~g}$ working fluid mass is advantageous in terms of thermal efficiency. The second column of Table 4 indicates the variation of the spring stiffness with the working fluid mass. At above 5 $\mathrm{g}$ mass of working fluid, the stiffness of the spring increases linearly with working fluid mass however, at below $5 \mathrm{~g}$ working fluid mass its decrease becomes sharper. As mentioned above, overlapping of PV diagrams is accomplished via using the interaction between PV diagrams and stiffness of the spring. Below $4.75 \mathrm{~g}$ and above $6.5 \mathrm{~g}$ working fluid mass, this interaction becomes inadequate. There is a need for another parameter to use for this purpose such as displacer rod diameters, damping constant, displacer mass etc. That means, these engines are able to work within limited change-ranges of design parameters.

Table 4. Variation of performance parameters with respect to working fluid mass

\begin{tabular}{|c|c|c|c|c|c|c|c|c|c|c|c|c|c|}
\hline $\begin{array}{c}m_{g} \\
(g)\end{array}$ & $\begin{array}{c}k \\
(k N / m)\end{array}$ & $\begin{array}{c}\omega \\
(\mathrm{rad} / \mathrm{s})\end{array}$ & $\begin{array}{c}\bar{M}_{q} \\
(\mathrm{Nm})\end{array}$ & $\begin{array}{c}W_{i} \\
(\mathrm{~J})\end{array}$ & $\begin{array}{c}W_{Q} \\
(\mathrm{~J})\end{array}$ & $\begin{array}{c}Q_{h} \\
(\mathrm{~J})\end{array}$ & $\begin{array}{c}Q_{c} \\
(\mathrm{~J})\end{array}$ & $\begin{array}{c}\eta_{e} \\
(\%)\end{array}$ & $\begin{array}{c}\eta_{i} \\
(\%)\end{array}$ & $\begin{array}{c}P_{e} \\
(W)\end{array}$ & $\begin{array}{c}P_{i} \\
(W)\end{array}$ & $\begin{array}{c}\phi \\
(\mathrm{deg})\end{array}$ & $\begin{array}{c}s \\
(\mathrm{~mm})\end{array}$ \\
\hline 4.75 & 116.6 & 294.81 & 8.832 & 64.72 & 63.21 & 220.83 & 157.63 & 25.13 & 29.30 & 2603.8 & 3036.5 & 106.2 & 37.1 \\
\hline 5.0 & 126.6 & 304.17 & 9.125 & 67.52 & 66.72 & 230.05 & 163.33 & 24.92 & 29.35 & 2775.5 & 3268.6 & 105.5 & 36.91 \\
\hline 5.5 & 136.9 & 318.11 & 9.54 & 72.5 & 72.4 & 250.06 & 177.66 & 23.98 & 28.99 & 3035.7 & 3670.6 & 105 & 36.80 \\
\hline 6.0 & 147.6 & 329.74 & 9.892 & 76.52 & 77.15 & 270.86 & 193.71 & 22.95 & 28.25 & 3261.8 & 4015.8 & 105 & 36.66 \\
\hline 6.5 & 158.7 & 338.38 & 10.15 & 77.80 & 76.92 & 290.18 & 213.26 & 21.98 & 26.81 & 3435.1 & 4190.3 & 105 & 36.54 \\
\hline
\end{tabular}




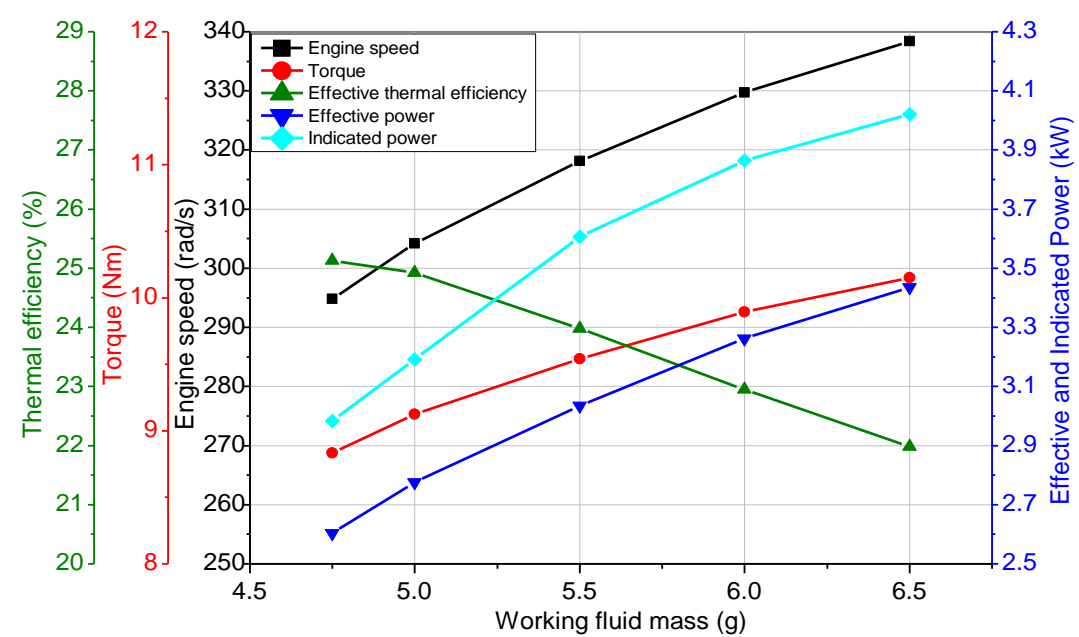

Figure 11. Variations of speed, torque, thermal efficiency, effective power and indicated power with working fluid mass.

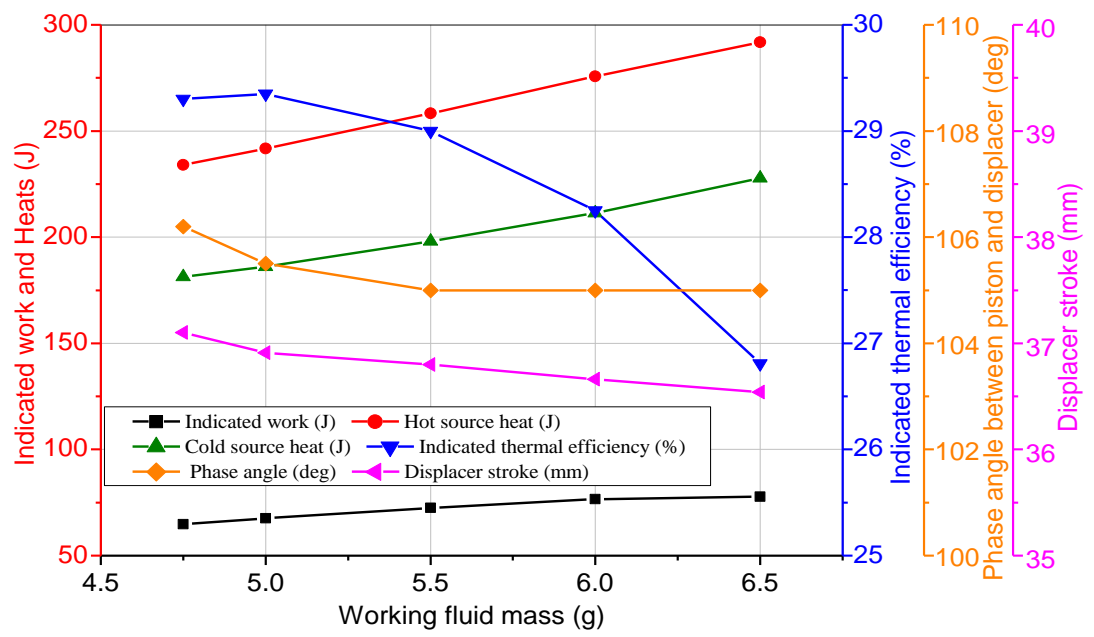

Figure 12. Variations of indicated work, hot source heat, cold source heat, indicated thermal efficiency, phase angle and displacer stroke with working fluid mass.

\section{Examination of Engine Performance with Respect to External Loading}

In this analysis, the external loading of the engine is considered to be accomplished with a fluid dynamometer. In such a case, the cyclic average of the external torque applied to the engine may be calculated as $\bar{M}_{q}=C_{q} \omega$ where $\omega$ and $C_{q}$ are the nominal speed of the engine and the torsional damping constant of the dynamometer. In this examination, $C_{q}$ varied between 0.028 and $0.034 \mathrm{Nsm} / \mathrm{rad}$. All other parameters were kept constant. Overlapping of PV diagrams is ignore however, while the variation interval of $C_{q}$ was limited in $0.028 \leq C \leq 0.034$, the diversity of PV diagrams was able to be disregarded. The mass of displacer and working fluid and spring constant were taken to be 1.353 $\mathrm{kg}, 6.5 \mathrm{~g}$ and $158700 \mathrm{~N} / \mathrm{m}$ respectively. Other inputs are given in Table 2 and 3. The results of this examination were presented in Figure 13 and Figure 14 as well as Table 5 .

As $C_{q}$ is varying from 0.028 to $0.034 \mathrm{Nsm} / \mathrm{rad}$, the engine speed $(\omega)$ remains almost constant. As long as the speed of the engine is controlled by the natural frequency of the displacer, the expected result is that the engine speed is constant. Since $\omega$ is constant and the relation between $C_{q}$ and torque is linear, the variation of torque with $C_{q}$ is expected to be linear. The values of the torque given in Table 5 verifies this expectation. It is shown in Figure 13 that the indicated work variation with $C_{q}$ is a decelerating increase. The increase of work is related to the phase angle variation. As seen from Table 5 and Figure 13, while $C_{q}$ increases, the phase angle approaches to $90^{\circ}$. As a result of these, heating and cooling occurs at more isochoric conditions and the efficiency of the thermodynamic cycle increases at a certain rate. As seen in Figure 13, the hot source heat is almost constant. This is a specific property of free displacer Stirling engines and its explanation is difficult. The variation of cold source heat is relatively higher. In Table 5, the effective and indicated thermal efficiencies are seen to be varying between 21.54-25.92\% and 25.67$31.56 \%$ respectively. As seen in Figure 14, variations of effective and indicated thermal efficiencies are not very similar to each other. While the effective thermal efficiency varied linearly, the indicated thermal efficiency deviates slightly from linearity. This may be caused by the irregularity of the work generation due to 
beating which is disregarded in this examination. Within the examined range of $C_{q}$, the effective power varies from $3256 \mathrm{~W}$ to $3870 \mathrm{~W}$, and the indicated power varies from $3880 \mathrm{~W}$ to $4713 \mathrm{~W}$. These variation ranges of effective and indicated powers are fair enough for practical implementations. On the other hand, the variations of powers are not limited in these ranges Beyond these ranges, the engine will continue to run and generate higher power but beating may be higher. As shown in Figure 14, the effective and indicated power curves are not very similar to each other as well which is also caused by beatings.

\section{CONCLUSION}

The thermodynamic and dynamic analysis of a free displacer Stirling engine has been conducted, and its practical problems and performance characteristics were investigated corresponding to displacer mass, working fluid mass and external load. It was determined that the starting speed of the engine was equal to the displacer natural frequency. At non-optimized working conditions, the work generation of the engine was found to be not uniform due to beating. At low values of the displacer mass, the engine provides higher performance. The circulation ratio of the working fluid between the hot and

Table 5. Variation of performance parameters with respect to external loading.

\begin{tabular}{|c|c|c|c|c|c|c|c|c|c|c|c|c|}
\hline $\begin{array}{c}C_{q} \\
(\mathrm{Nms} / \mathrm{rad})\end{array}$ & $\begin{array}{c}\omega \\
(\mathrm{rad} / \mathrm{s})\end{array}$ & $\begin{array}{c}\bar{M}_{q} \\
(\mathrm{Nm})\end{array}$ & $\begin{array}{c}W_{i} \\
(J)\end{array}$ & $\begin{array}{c}W_{Q} \\
(J)\end{array}$ & $\begin{array}{c}Q_{h} \\
(J)\end{array}$ & $\begin{array}{c}Q_{c} \\
(J)\end{array}$ & $\begin{array}{c}\eta_{e} \\
(\%)\end{array}$ & $\begin{array}{c}\eta_{i} \\
(\%)\end{array}$ & $\begin{array}{c}P_{e} \\
(W)\end{array}$ & $\begin{array}{c}P_{i} \\
(W)\end{array}$ & $\begin{array}{c}\phi \\
(\mathrm{deg})\end{array}$ & $\begin{array}{c}s \\
(\mathrm{~mm})\end{array}$ \\
\hline 0.028 & 341.0 & 9.548 & 71.49 & 70.07 & 278.5 & 208.42 & 21.54 & 25.67 & 3256 & 3880 & 104.6 & 36.03 \\
\hline 0.029 & 337.76 & 9.795 & 73.07 & 72.46 & 278.94 & 206.47 & 22.06 & 26.19 & 3308 & 3928 & 103.5 & 36.18 \\
\hline 0.030 & 337.68 & 10.13 & 77.30 & 79.01 & 280.37 & 201.35 & 22.70 & 27.57 & 3421 & 4154 & 102.8 & 36.45 \\
\hline 0.031 & 337.58 & 10.465 & 80.699 & 81.65 & 280.51 & 198.85 & 23.44 & 28.77 & 3533 & 4336 & 101.2 & 36.62 \\
\hline 0.032 & 337.53 & 10.801 & 84.14 & 84.94 & 279.05 & 194.11 & 24.32 & 30.15 & 3646 & 4520 & 97.6 & 36.92 \\
\hline 0.033 & 337.44 & 11.136 & 86.646 & 84.97 & 278.5 & 193.53 & 25.12 & 31.11 & 3758 & 4653 & 95.6 & 37.13 \\
\hline 0.034 & 337.39 & 11.471 & 87.77 & 88.33 & 278.03 & 189.7 & 25.92 & 31.56 & 3870 & 4713 & 93.3 & 37.44 \\
\hline
\end{tabular}

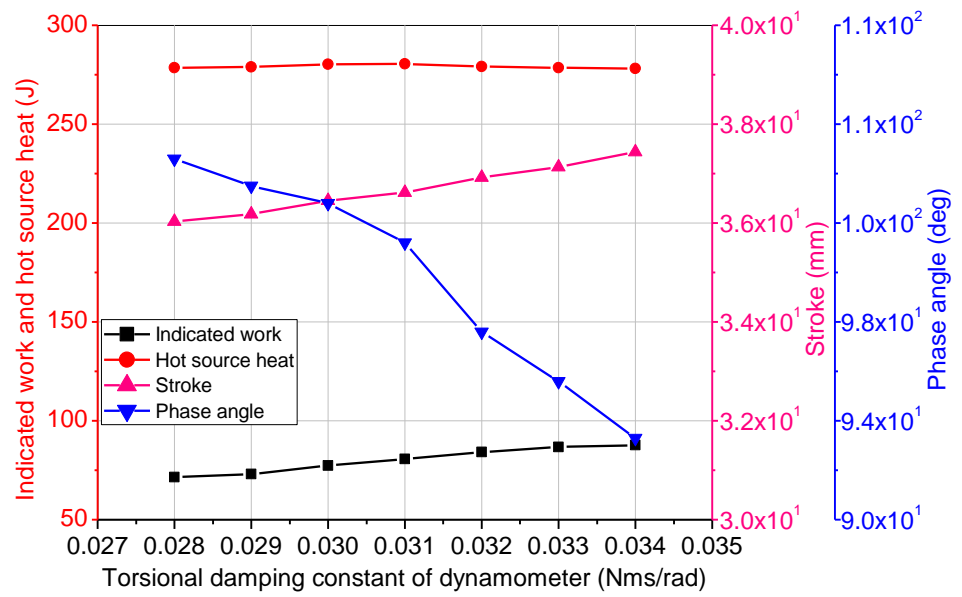

Figure 13. Variations of indicated work, hot source heat, stroke and phase angle with $C_{q}$.

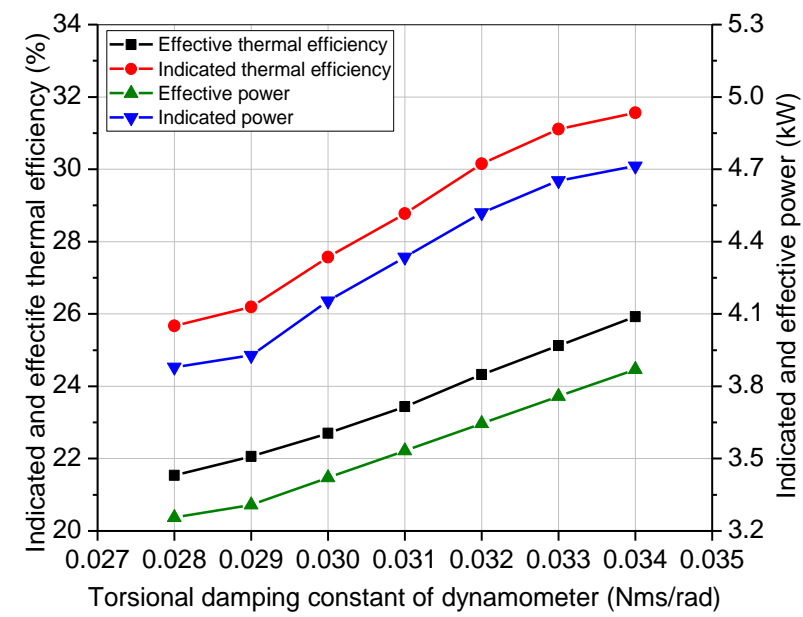

Figure 14. Variations of effective and indicated efficiencies and powers with $C_{q}$. 
cold compartments of the displacer cylinder was found tobe comparatively lower than the other types of Stirling engines, and as a result of this, the thermal efficiency and other performance values of the engine were found to be a bit lower. While the working fluid mass is increasing, the thermal efficiency of the engine becomes lower, but speed, power and torque increase by slowing down. The displacer stroke of the engine exhibits a little variation, but its influence on the engine performance is insignificant. As the external load increases within a certain range, the thermal performance of the engine increases while speed remained almost constant. An engine with 3.5-liter inner volume provides $3.9 \mathrm{~kW}$ effective power and $26 \%$ effective thermal efficiency at $1000 \mathrm{~K}$ heater temperature, $356 \mathrm{~K}$ cooler temperature and 18 bar working fluid charge pressure.

\section{REFERENCES}

Abbas M, Boumeddane B, Said N, Chikouche A. Dish Stirling technology: A $100 \mathrm{MW}$ solar power plant using hydrogen for Algeria. International Journal of Hydrogen Energy, 2011;36:4305-4314.

doi.org/10.1016/j.ijhydene.2010.12.114.

Altin M, Okur M, Ipci D, Halis S, Karabulut $\mathrm{H}$. Thermodynamic and dynamic analysis of an alpha type Stirling engine with Scotch Yoke mechanism. Energy, 2018;148:855-865. doi:10.1016/j.energy.2018.01.183

Begot S, Layes G, Lanzetta F, Nika P. Stability analysis of a free piston Stirling engines. The European Physical Journal Applied Physics, 2013;61:30901. doi:10.1051/epjap/2013120217.

Cheng CH, Yang HS, Jhou BY, Chen YC, Wang YJ. Dynamic simulation of thermal-lag Stirling engines. Applied Energy, 2013;108:466-476. doi 10.1016/j.apenergy.2013.03.062.

Chi C, Moua J, Lina M, Honga G. CFD simulation and investigation on the operating mechanism of a beta-type free piston Stirling engine. Applied Thermal Engineering, 2020;166:114751. doi: 10.1016/j.applthermaleng.2019.114751.

De la Bat BJG, Dobson RT, Harms TM, Bell AJ. Simulation, manufacture and experimental validation of a novel single acting free-piston Stirling engine electric generator. Applied Energy, 2020;263:114585. doi:10.1016/j.apenergy.2020.114585.

Formosa F. Coupled thermodynamic-dynamic semianalytical model of free piston Stirling engines. Energy Conversion and Management, 2011;52:2098-2109. doi:10.1016/j.enconman.2010.12.014.

Karabulut H. Dynamic analysis of a free piston Stirling engine working with closed and open thermodynamic cycles. Renewable Energy, 2011;36:1704-1709. doi:10.1016/j.renene.2010.12.006.
Karabulut H, Cinar C, Okur M. Dynamic simulation and performance prediction of free displacer Stirling engines. International Journal of Green Energy, 2020;17(7):427439. doi:10.1080/15435075.2020.1761814.

Karabulut H, Okur M, Ozdemir AO. Performance prediction of a Martini type of Stirling engine. Energy Conversion and Management, 2019;179:1-12. doi:10.1016/j.enconman. 2018.10.059.

Kwankaomeng S, Silpsakoolsook B, Savangvong P. Investigation on stability and performance of a freepiston Stirling engine. Energy Procedia, 2014;52:598609. doi:10.1016/j.egypro.2014.07.115.

Lin M, Mou J, Chi C, Hong G, Ge P, Hu G. A space power system of free piston Stirling generator based on potassium heat pipe. Frontiers in Energy, 2020;14(1):110. doi:10.1007/s11708-019-0655-6.

Majidniya M, Boileau T, Remy B, Zandi M. Nonlinear modeling of a free piston Stirling engine combined with a permanent magnet linear synchronous machine. Applied Thermal Engineering, 2020;165:114544. doi:10.1016/j.applthermaleng.2019.114544.

Masoumi AP, Tavakolpour-Saleh AR. Experimental assessment of damping and heat transfer coefficients in an active free piston Stirling engine using genetic algorithm. Energy, 2020;195:117064. doi:10.1016/j.energy.2020.117064.

Mehdizadeh NS, Stouffs P. Simulation of a Martini displacer free piston Stirling engine for electric power generation. International Journal of Applied Thermodynamics, 2000;3(1):27-34. doi:10.5541/ijot.30.

Mou J, Hong GA. A numerical model on thermodynamic analysis of free piston Stirling engines. IOP Conference Series: Materials Science and Engineering, 2017;171:012090. doi:10.1088/1757899X/171/1/012090.

Park J, Ko J, Kim H, Hong Y, Yeom H, Park S, In S. The design and testing of a $\mathrm{kW}$-class free-piston Stirling engine for micro-combined heat and power applications. Applied Thermal Engineering, 2020;164:114504. doi:10.1016/j.applthermaleng.2019.114504.

Tanaka M, Yamashita I, Chisaka F. Flow and heat transfer characteristics of the Stirling engine regenerator in an oscillating flow. JSME International Journal, 1990;33(2):283-289. doi:10.1299/jsmeb1988.33.2_283.

Tavakolpour-Saleh AR. Zare SH, Bahreman H. A novel active free piston Stirling engine: modeling, development, and experiment. Applied Energy, 2017;199:400-415. doi:10.1016/j.apenergy.2017.05.059.

Wood JG, Lane N. Advanced 35 W free-piston Stirling engine for space power applications. AIP Conference Proceedings 2003;654:662-667. doi:10.1063/1.1541353. 
Ye W, Yang P, Liu Y. Multi-objective thermodynamic optimization of a free piston Stirling engine using response surface methodology. Energy Conversion and Management, 2018;176:147-163.

doi:10.1016/j.enconman.2018.09.011.

Zare S, Tavakolpour-Saleh AR. Predicting onset conditions of free piston Stirling engine. Applied Energy 2020;262:114488. doi:10.1016/j.apenergy.2019.114488.

Zare S, Tavakolpour-Saleh AR, Sangdani MH. Investigating limit cycle in a free piston Stirling engine using describing function technique and genetic algorithm. Energy Conversion and Management, 2020;210:112706.

doi:10.1016/j.enconman.2020.112706
Zhou Q, Xia Y, Liu G, Ouyang X. A miniature integrated nuclear reactor design with gravity independent autonomous circulation. Nuclear Engineering and Design, 2018;340:9-16.

doi:10.1016/j.nucengdes.2018.09.013.

Zhu S, Yu G, Ma Y, Cheng Y, Wang Y, Yu S, Wu Z, Dai W, Luo E. A free-piston Stirling generator integrated with a parabolic trough collector for thermal-to-electric conversion of solar energy. Applied Energy, 2019;242:1248-1258.

doi:10.1016/j.apenergy.2019.03.169.

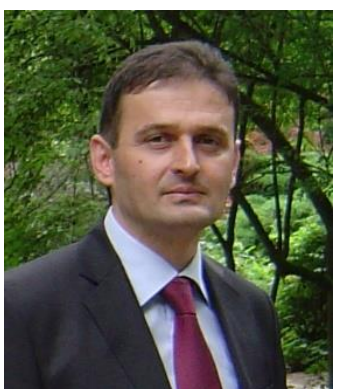

Can CINAR was born in Eskișehir in 1975. In 1996, he graduated from Automotive Education Program at Technical Education Faculty of Gazi University. He completed his MSc and PhD degrees in the Department of Mechanical Education in Graduate School of Natural and Applied Sciences at Gazi University, in 1998 and 2001. He worked as a Research Assistant between 1996- 2002, as an Instructor Doctor between 2002-2003, and as an Assistant Professor between 2003-2008 at the Faculty of Technical Education of Gazi University. He became Associate Professor in 2008. He has been working as a Professor at the Department of Automotive Engineering at the Faculty of Technology in Gazi University since 2013.

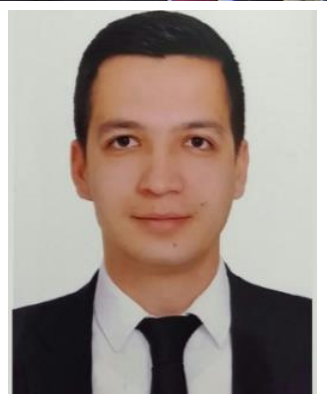

Abdullah Onur ÖZDEMİR graduated from Automotive Education and Mechanical Engineering bachelor programs. He completed his MSc degree in Mechanical Education. He received his $\mathrm{PhD}$ degree in the field of Automotive Engineering. Ozdemir is working as a Research Assistant in the Department of Automotive Engineering at Gazi University, Turkey. His researches focus on engine thermodynamic cycle analysis and thermoplastic composites.

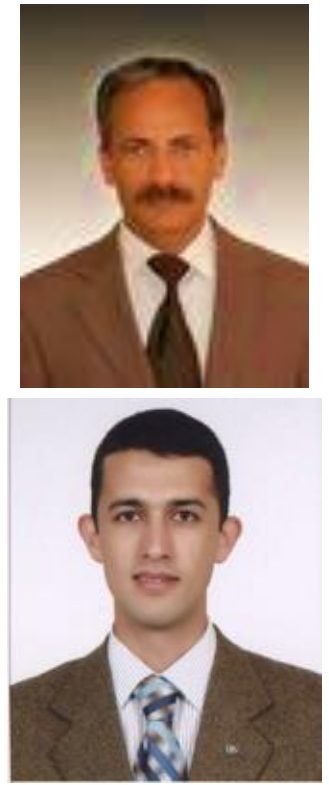

Halit KARABULUT was born in 1959 in Antalya. He graduated from the Higher Technical Teachers Academy in 1980. In 1987, he completed his MSc degree at the Mechanical Education Department, Institute of Science, Gazi University. He completed his PhD at Heriot-Watt University in 1991. In 1992, he was appointed as Assistant Professor at Technical Education Faculty, Gazi University. In 1997, he became an Associate Professor at the Technical Education Faculty of Gazi University. In 2000, he was assigned as an Associate Professor at Akdeniz University. In 2003, he became a Professor at the Technical Education Faculty, Gazi University. He has been working as a Professor at Automotive Engineering Department of Technology Faculty at Gazi University, since 2011.

Mesut DÜZGÜN is currently a lecture of Automotive Engineering Department at the Gazi University, which he joined in 2002. He received his first B.E. in Automotive Education Department in 2000, from Gazi University in Turkey. He graduated from the Gazi University with Graduate School of Natural and Applied Sciences an M.Sc. in 2002 and received his Ph.D. degree; in 2008 to Gazi University. After working for 2 years in the Republic of Turkey Ministry of National Education, he joined the Gazi University as a Research Assistant Automotive Department in 2002. He became an Assistant Professor in the same department in 2009 and he became an Associate Professor in 2017. His current research areas are Vehicle Dynamics, Vehicle Technology and Engine Technologies. He is specialized in the field of brake systems and applications. He has worked on some projects in vehicle technology area and as researcher in numerous international projects in Turkey. 